\title{
Operations research in areas of civil engineering and sustainable development: EURO working group activities
}

\author{
Edmundas Kazimieras Zavadskas \\ Chairman of Department of Construction \\ Technology and Management at the Faculty \\ of Civil Engineering, Vilnius Gediminas \\ Technical University \\ edmundas.zavadskas@vgtu.lt
}

\author{
Tatjana Vilutienè \\ EWG-ORSDCE coordinator \\ Vilnius Gediminas Technical University \\ tatjana.vilutiene@vgtu.lt
}

DOI 10.5592/otmcj.2013.1.1 Invited paper

THE VIEWPOINT PRESENTED IN THIS PAPER PROMOTES THE COLLABORATION, PARTNERING AND EXCHANGE OF BEST PRACTICE KNOWLEDGE AS KEY FACTORS TO REAP BENEFITS FOR CONSTRUCTION EXCELLENCE AND SUSTAINABILITY. The approach uses the example of EURO Working Group "OR in Sustainable Development and Civil Engineering" activities. EURO is the 'Association of European Operational Research Societies' within IFORS, the 'International Federation of Operational Research Societies'.

\section{The context of activity}

Organizations in construction industry during their life cycle are constantly involved in various types of projects. So the success of the project as temporary organization is affected by the resources and effectiveness of the corporate organizations; and the success of the organization also affected by the performance and success of every separate project. Different stakeholders of construction process (institutions, society, construction industry representatives, and government) also influence the performance of construction sector, mainly through regulatory mechanisms, information dissemination, training and research.

The topics of project performance and success factors are discussing widely by professionals for a long time.
As success factors influencing the good performance of projects in construction many researches mentioned: cooperation among project participants; the use of high-performance work systems; project manager's competence; top management support; project manager's coordinating and leadership skill; owner's competence; the application of methods and techniques in decisionmaking process.

Obviously, the important role in future development of construction industry will have the application of new techniques and methods, which could raise the efficiency of processes. Traditional optimization, statistical and econometric analysis approaches used within the engineering context are often based on the assumption that the considered problem is well formulated and decision-makers usually consider 
the existence of a single objective, evaluation criterion or point of view that underlies the conducted analysis. In such a case the solution of engineering problems is easy to obtain. But in reality, the modelling of engineering problems is based on a different kind of logic taking into consideration the conflicting aims of decision makers, the existence of multiple criteria, the complex, subjective and different nature of the evaluation process. Therefore, multiple criteria methods contribute in engineering context through the identification of the optimal alternatives taking into account the conflicts between the criteria and the revealing the preferences.

Emphasizing the importance of aforementioned issues and striving to contribute to resolving the conflicts between the various competing goals in pursuit of economic prosperity, environmental quality and technological efficiency the EURO Working Group "Operations Research in Sustainable Development and Civil Engineering” (hereinafter - Working Group) raises the following objectives:

$\checkmark$ to develop and apply the multiple criteria methods in the fields of sustainable development and civil engineering;

$\checkmark$ to promote the innovations based on application of multiple criteria methods in construction industry;

$\checkmark$ to facilitate the collaborations between European researchers working in field of OR in civil engineering and sustainable development;

to ensure the continuity and progress of work and to transfer for scientific communities and construction industry the ideas of multiple criteria decision aiding, the results of work, thoughts and important discussions of group members.

The fields of the research concentrate in three broad fields: Operational Research, Civil Engineering and Sustainable Development. On the top of that the primary purpose of the Working Group is to stimulate collaboration in area of OR in sustainable development and civil engineering.

\section{History}

The decision to establish EURO Working Group “OR in Sustainable Development and Civil Engineering" was taken after a long international collaboration between researchers from several European countries (Lithuania, Germany, Poland, United Kingdom, Belgium, Denmark, Latvia, Estonia, Czech Republic, Slovenia). The working group was created at EURO Conference XXIII in 2009, Bonn (Germany). Currently group joins more than $100 \mathrm{sci}$ entists from 20 countries (Lithuania, Germany, Poland, United Kingdom, Belgium, Denmark, Netherlands, Portugal, Latvia, Estonia, Czech Republic, Slovenia, Russia, Ukraine, Australia, Iran, USA, Taiwan and others), but at the early beginning research group consisted of the professors from the only Lithuanian, German and Polish academic and research centres. Marking the importance and the uniqueness of the beginning of collaboration this research group was later in articles referred to as the "scientific triangle".

Collaboration in exchanging of research achievements, consulting on publications, cooperating in joint papers, supporting the future research was realized through organization of colloquiums, which were held every two year in the different academic centres and cover different areas. As the examples, the topic of 13 th colloquium held in 2011 was "Civil Engineering Projects" and the topic of 14 th colloquium hold this year is "Innovative solutions in construction technology and management".

Scientific cooperation started by three academic centers: the Leipzig University of Applied Sciences (Applied Sciences - Germany), Vilnius Gediminas Technical University (Vilnius Gediminas Technical Univer- sity - Lithuania) and Poznan University of Technology (PUT - Poland) in form of colloquia in 2011 celebrated the twenty-five-year anniversary.

Every colloquium from the first one held in 1986 and to the last had given the considerable contribution to the publication of research papers and books, development of research, preparing doctoral dissertations and for international recognition. The cooperation resulted with scientific results: written 45 scientific books, including 8 scientific monographs; more than four hundred articles published in scientific journals; 13 professors defended a habilitation or passed habilitation procedure; 54 doctoral students defended doctoral dissertations in field of civil engineering; six scientific publications in 2006, 2010, 2011 and 2012 by ScienceWatch.com were selected as Top cited and Hot articles in mathematics, engineering and business fields; a few European patents were the registered. The institutions have signed the exchange agreements under which teachers and students exchanges more than twenty years. The invention of research team of EWG-ORSDCE members "Electronic information search method and system" in Lithuania has been recognized as the best invention of August, 2010.

Every year EURO working group presents the results of scientific cooperation in annually issued Newsletter available on Web page http://www. orsdce.vgtu.lt.

\section{New optimization methods}

The methods of multi-attribute analysis were tested in many fields and applied to different disciplines as well as to solving many specific problems. In spite of these facts, multi-attribute analysis is not sufficiently developed, the methods are not perfect, and scientists constantly raise the question, "Which is the best method for a given problem?" Most of the methods enable us to determine the priority rank for 
comparing the alternatives, not allowing, however, to establish the level at which one alternative can be better than another. The members of EWGORSDCE have created a series of new optimization methods, which were successfully applied in different fields:

- The COmplex Proportial ASsesment (COPRAS) in 1996 (by Zavadskas E.K. and Kaklauskas A.)

- Multi Objectives Optimization by Ratio Analysis (MOORA) in 2006 (by Brauers W.K. and Zavadskas E.K.)

- MULTIMOORA in 2010 (by Brauers W. K. M. and Zavadskas E. K.)

- Additive Ratio ASsessment method (ARAS) in 2010 (by Zavadskas E. K. and Turskis Z.)

- Weighted Aggregates Sum Product ASsessment method (WASPAS) in 2012 (by Zavadskas E.K., Turskis Z., Antucheviciene J. and Zakarevicius $A$.

- SyMAD-3 (synthesis method of structural, technological and safety decisions) in 2012 (by Simanavičienè R., Liaudanskienė R. and Ustinovičius L.) The successful cooperation between the stakeholders during the construction life cycle results a smooth flow of construction processes. However, the fact that construction environment is usually uncertain, unstable and therefore unpredictable should be taken into account. Technical solutions and managerial decisions made in such environment should be substantiated by proper methods, which let to process not complete and expressed in certain ranges (intervals) data. The correct methodological approach let to avoid unwanted disputes and other undesirable obstacles that impede the construction process and led to delays. To process the uncertain data expressed in intervals the members of EWG-ORSDCE introduced the modifications of earlier created methods:

- SAW-G in 2010 (by Zavadskas E. K., Vilutienė T., Turskis Z., Tamošaitienė J.)

- Complex Proportional ASsessment method with Grey interval numbers
(COPRAS-G) in 2008 (by Zavadskas E. K., Kaklauskas A., Turskis Z. and Tamošaitienè J.)

Grey Additive Ratio Assessment method (ARAS-G) in 2010 (by Turskis Z. and Zavadskas E.K.)

For rational dispute resolution Keršulienè, V., Zavadskas, E. K. and Turskis, Z. in 2010 offered the Stepwise weight assessment ratio analysis (SWARA) method. In 2008 a new logarithmic normalization method was presented. In 2006 FARE (Factor Relationship) method, allowing to determine the weights of a large number of criteria based on the relationship between one of them and the others was presented by Ginevičius $R$.

Uncertainty and imprecision involving multiple criteria, the intersection of goals and constraints could result the necessity to use the fuzzy logic in decision making. Fuzzy logic is an extension of the traditional logic to intermediate and approximate values that capture the meaning of words, human reasoning, and decision making. For multi-attribute selection of an alternative under uncertainty conditions E.K.Zavadskas, L.Ustinovičius, Z.Turskis, F.Peldschus and D.Messing created and in 2002 announced the software LEVI-3.0 based on different methods for attributes normalization and optimal variant selection. The application of these methods increases the accuracy of determining an optimal decision. With new software it is possible to find solution of rational strategy problem using different methods under risk and uncertainty and to compare the results. To process the fuzzy data the members of EWG-ORSDCE introduced the methods:

- Fuzzified method of Complex Proportional ASsessment (COPRASF) in 2007 (by Zavadskas E.K. and Antuchevičienèj.)

- Fuzzy additive ratio assessment method (ARAS-F) in 2010 (by Zavadskas E. K. and Turskis Z.)

By applying the methods of multiattribute analysis to different cases the authors of research papers noticed the regularities and pointed the statements that should be considered in further applications. For example, for the reason to make the efficient decision it is purposeful to use not large number of attributes including their weights. Considering the large number of attributes and ignoring their weights the less important attributes have high influence on final result. Therefore, the risk exists that irrational decision could be selected. Moreover, when the variants are characterized by large number of attributes rated in 10 points scale with the accuracy of calculation is 0,5 point, or $5 \%$ the attributes with significance less than $5 \%$ have less influence of final result than the values of possible errors and could be eliminated from decision-making matrix.

\section{Other initiatives}

The members of EWG-ORSDCE are active on international level promoting collaboration in broad research areas. The members of EWG-ORSDCE were among the founders of new organization called International Academy of Information Technology and Quantitative Management (IAITQM). The inauguration meeting of IAITQM took place in Omaha of United States on June 3 , 2012. The Academy was established at a right time to consider how to physically bring educators, scholars, policy makers, and professionals around the world in the fields of information technology and quantitative management together to exchange their fresh thoughts, creative ideas, research findings and business experience to further benefit humanity.

The members of EWG-ORSDCE are chief editors and active members of editorial boards of the scientific journals. The efficient management resulted that the four of them have received the impact factors and high ranks:

> Journal of Civil Engineering and Management (IF=2.171 (2011);

> Technological and Economic Devel- 
opment of Economy (IF=3.235 (2011);

$>$ Journal of Business Economics and Management ( $\mathrm{IF}=2.388$ (2011). Ranking: 22/113 (Business) and 26/320 (Economics);

> International Journal of Strategic Property Management (IF=1.620 (2011). Ranking: 56/168 (Management);

- The Baltic Journal of Road and Bridge Engineering ( $\mathrm{IF}=1.610$ (2011);

> Journal of Environmental Engineering and Landscape Management (IF=1.958 (2011).

The sustainability ideas are promoted not only through publication of articles, but also by the implementation of scientific projects. The research team of EWG-ORSDCE members implements $7^{\text {th }}$ Framework project "Sustainable zero carbon ECO-town developments improving quality of life across EU (ECO-life)" $(2010$ - 2016) that promotes the sustainable green city concept and aims to implement the renovation of town district to high energy standard using RES.

In 2012 started BUILD UP Skills project funded under Intelligent Energy Europe (IEE) program. BUILD UP Skills is an EU Initiative to improve the qualification and skills of Europe's building workers which are essential to build, equip and renovate buildings of high energy performance.

Another project finalizing this year granted under the "Priority1: Fostering Innovations" of the Baltic Sea Region Programme 2007-2013 "COOL Bricks - Climate Change, Cultural Heritage \& Energy Efficient Monuments" initiated in order to find the ways how to reduce the energy consumption of historical buildings without destroying their cultural value and identity. Project aims to find common solutions to combine the needs of climate protection with technical, administrative and historically adequate approaches to fulfil the necessary $\mathrm{CO}_{2}$-reduction aims.

The NorthPass project (2009-2012) funded under Intelligent Energy Europe (IEE) program was aimed at promoting the very low-energy house concept in the North European building market, focusing on new residential buildings. The expected results of project are: defined very-low energy house criteria and concept adapted to the North European countries; solutions to remove the market barriers; removed gaps between demonstration and broad market penetration.

Efficient and innovative construction industry is crucial factor in rising quality of life. As construction knowledge, technology and experience progressed through the ages in the realization of major construction projects; various innovative technological developments appeared and were described in many scholarly publications. The important role in future development of construction industry will have the application of new techniques and methods, which could raise the efficiency of processes. Collaboration and exchange of best practice knowledge can also provide extensive benefits to the industry. And finally, we would like to point out that multiple criteria decision making methods have a promising future in the construction management field, because they offer a highly approved methodological basis for decision support. Nevertheless, their success in practice depends heavily on the development of computerized multicriteria decision support systems for variety of problems to be solved.

\section{References:}

Skibniewski, M. J. and Zavadskas, E.K. (2013) Technology development in construction: a continuum from distant past into the future, Journal of Civil Engineering and Management, Vol. 19 No. 1, pp. 136-147.

Tamošaitienė, J.; Bartkienè, L.; Vilutienè,

T. (2010) The new development trend of operational research in civil engineering and sustainable development as a result of collaboration between German-LithuanianPolish scientific triangle, Journal of Business Economics and Management, Vol. 11 No.2, pp. 316-340.

Zavadskas, E.K. and Turskis, Z. (2011) Multiple criteria decision making (MCDM) methods in economics: an overview, Technological and Economic Development of Economy, Vol. 17, Iss. 2, pp. 397-427.

http://www.orsdce.vgtu.lt/

http://www.ecolife-project.eu/

http://www.buildupskills.eu/

www.co2olbricks.eu

http://northpass.ivl.se/ 